\title{
Study Habits of Higher Secondary Students of Shillong in Mathematics
}

\author{
R. Lamar, \\ Asst. Professor, Dept. Of Mathematics, St. Mary's College, and Shillong)
}

\begin{abstract}
The study was undertaken to find out the Study Habits of Higher Secondary Students towards Mathematics. The researcher selected 200 Higher Secondary Students from 5 Higher Secondary Schools in Shillong. The researcher used the "Study Habit Inventory by Dr B.V. Patel to collect the data from the students. Appropriate statistical techniques like percentage, Mean and S.D. were worked out to find the nature of score distribution of the data collected. The 't' test was applied to find out the significance of difference between different male and female students.
\end{abstract}

\section{Introduction}

Study habits play an important role in the achievement of the students at all levels of Education. Habits usually help students to do something with less thought and effort. They are important in shaping the personalities of individuals. In the process of Education study habits like thinking, reasoning, concentration, punctuality etc, enables the students to make proper adjustments for better achievements. Harry Maddox (1963) states that success in academic study depends not only on ability and hard work but also on effective method of study. Srivastava (1967) points out that for good academic success, good study habits and attitudes are important. Further Percival and Ellington (1984) states that habit refers to the method or techniques of effective learning which in turn involve a set of study skills such as organisation of time, effective use of time, reading skills, essay writing, report writing skills, note-taking, examination techniques and even job hunting skills.

Studying is a skill. Being successful in school requires a high level of study skills. First, students must learn these skills, practice them and develop effective study habits in order to be successful. Very often the study habits and practices developed and used in Higher Secondary Schools do not work for students in College. Good study habits include many different skills: time management, self discipline, concentration, memorization, organization and effort. Desire to succeed is important.

\section{Objectives}

The following objectives were formulated for the present study>

1. To study the Study Habits of Higher Secondary School Students in Mathematics.

2. To find out the difference in the study habits of Male and Female Higher Secondary School Students in Mathematics.

3. To study the difference in the study habits of Tribal and Nontribal Higher Secondary School Students in Mathematics.

\section{Hypotheses}

The following research hypotheses were tested in the present study.

1. There is no significant difference in the study habits of Male and Female Higher Secondary School Students.

2. There is no significant difference in the study habits of Tribal and Nontribal Higher Secondary School Students.

(i) Method

\section{Methodology}

The Descriptive Method was used in the study.

(ii) Sample

Random Sampling technique was used to select the sample. The study was conducted on a sample of 285 Higher Secondary School Students of Class XII from the Science Stream having Mathematics as one of the subject.

Table 1. Showing Sample of the Study

\begin{tabular}{|l|l|l|l|}
\hline Community & Male & Female & Total \\
\hline Tribal & 92 & 48 & 140 \\
\hline Nontribal & 85 & 60 & 145 \\
\hline Total & 177 & 108 & 285 \\
\hline
\end{tabular}


(iii) Tool Used

The tool used for the present study was the "A Study Habit Inventory" by Prof M.Mukhopadhyaya and Prof D.N. Sansanwal. This tool was used to measure the study habits of Higher Secondary School Students under 9 components, viz. Comprehension, Concentration, Task Orientation, Sets, Interaction, Drilling, Support, Recording, and Language.

\section{(iv) Procedure}

The scale was administered to 285 Class XII Higher Secondary Students of the Science Stream of schools in Shillong. The students were asked to read the instructions very carefully before giving their responses. The researcher also requested them to respond to all the items. The responses of the students were then scored on the bases of components. The obtained data was tabulated and analysed.

\section{Analysis and Interpretation of Data}

The analysis of data was done on the sequence of the objectives stated above. Descriptive statistics were used to analyse the data.

Objective I: To study the Study Habits of Higher Secondary School Students in Mathematics Mathematics.

The following table shows the overall Study Habits of Higher Secondary Students towards

Table 2: Showing the Overall Study Habit of Higher Secondary Students in Mathematics

\begin{tabular}{|l|l|l|l|l|}
\hline S1 no & Categories & Range of Scores & No of Students & $\%$ \\
\hline 1 & Good Study Habit & 187 to 280 & 66 & 23.16 \\
\hline 2 & Average Study Habit & 94 to 187 & 124 & 43.51 \\
\hline 3 & Low Study Habit & Below 94 & 95 & 33.33 \\
\hline & Total No. of Students & 285 & \\
\hline
\end{tabular}

\section{Interpretation}

Table 2 above shows that there are variations in the Study Habits of Higher Secondary Students towards Mathematics. $23.16 \%$ of the students had Good Study Habits and $43.51 \%$ were placed under the Average Study Habits; $33.33 \%$ of the students had Low Study Habits. This shows that majority of students had Average Study Habits.

Objective 2: To find out the difference in the study habits of Male and Female Higher Secondary School Students in Mathematics. Mathematics.

The following table shows the study habits of Male and Female Higher Secondary Students towards

Table 2: Study Habits of Male and Female Higher Secondary Students in Mathematics

\begin{tabular}{|l|l|l|l|l|l|l|l|}
\hline & Students & $\mathbf{N}$ & $\begin{array}{l}\text { Maximum } \\
\text { Score }\end{array}$ & $\mathbf{M}$ & SD & 't' & Remark \\
\hline $\begin{array}{l}\text { Study } \\
\text { Habits }\end{array}$ & Male & 177 & 280 & 135.86 & 16.05 & 3.96 & \begin{tabular}{l} 
Significant at \\
\cline { 2 - 8 }
\end{tabular} \\
\cline { 2 - 7 }
\end{tabular}

$\mathrm{Df}=283$

\section{Interpretation}

To verify hypothesis 1, scores obtained by Male and Female Higher Secondary Students on Study Habits in Mathematics were entered in. The Mean Attitude Scores and S.D. of Male and Female Students were calculated and entered in the table above. Further the ' $t$ ' value was calculated to test the significance of difference between Mean Scores of Male and Female students on Study Habits in Mathematics. The table reveals that there is a significant difference between the Male and Female Higher Secondary Students at 0.01Level. Therefore the null hypothesis is rejected.

Objective 3: To study the difference in the study habits of Tribal and Nontribal Higher Secondary School Students in Mathematics.

The following table shows the Attitude of Tribal and Nontribal Higher Secondary Students towards Mathematics. 
Study Habits of Higher Secondary Students of Shillong in Mathematics

Table 3: Study Habits of Tribal and Nontribal Higher Secondary Students in Mathematics

\begin{tabular}{|l|l|l|l|l|l|l|l|}
\hline & Students & $\mathbf{N}$ & $\begin{array}{l}\text { Maximum } \\
\text { Score }\end{array}$ & M & SD & 't' \\
\cline { 1 - 7 } $\begin{array}{l}\text { Study } \\
\text { Habits }\end{array}$ & Tribal & 140 & 280 & 120.82 & 14.02 & 5.63 & Significant at \\
\cline { 2 - 7 } & Nontribal & 145 & 280 & 138.43 & 15.85 & 0.01 level \\
\hline
\end{tabular}

Df $=283$

\section{Interpretation}

To verify hypothesis 2, scores obtained by Tribal and Nontribal Higher Secondary Students on Study Habits in Mathematics were entered in. The Mean Attitude Scores and S.D. of Tribal and Nontribal Students were calculated and entered in the table above. Further the ' $t$ ' value was calculated to test the significance of difference between Mean Scores of Tribal and Nontribal students on Study Habits in Mathematics. The table reveals that there is a significant difference between the Tribal and Nontribal Higher Secondary Students at 0.01Level. Therefore the null hypothesis is rejected.

\section{Major Findings of the Study}

On the basis of the analysis and interpretation of the data, the following conclusions were drawn.

The findings indicate that majority of the Higher Secondary School Students were average in their Study Habits. However, it can also be seen that $33.33 \%$ were placed in the Low Study Habits and $23.16 \%$ were under the Good Study Habit Category.

There was a significant difference between the study habits of Male vs Female Higher Secondary Students and Tribal and Non-Tribal Higher Secondary School Students in Mathematics. It was observed that the 't'values were significant at 0.01 level. Therefore Hypothesis 1 and 2 were rejected.

\section{Conclusion}

The syllabus for mathematics should be restructured to meet the needs of the students so that they can become more interested in studying and learning mathematics. Teachers need to be well trained in order to used appropriate teaching methods and techniques which will help the students to create more interest in learning mathematics. The school should also develop a strategy to improve the level of learning mathematics for the low study habit students. If students do not study well and put all efforts to improve their study habits, their achievement level might drop down. So there is a need to develop the study habits of the students to attain more satisfactory marks in mathematics. Thus to sustain and to increase good study habits in Mathematics, special concern is to be extended among the students' homework and classwork / assignments. Students can also be instructed to plan a scheduled of balanced learning activities for Mathematics.

\section{References}

[1] Best.J.W. \& Kahn, J.V (2005). Research in Education, Prentice Hall of India, New Delhi.

[2] Garrett, H.E. (2007). Statistics in Psychology and Education, International Publisher, New Delhi .

[3] Jamuar, K.K. (1974). Study Habit of College Students, International Publications, Allahabad.

[4] Kurukshetra, K.U, Stella, S and Purushothanan, S. (1993). "Study Habits of Under Achievers". Journal of Educational Research, 29 (4)

[5] Preston, Rah (1959). Teaching Study Habits and Skills, Rinehart. University of Maryland 